\title{
Effect of Shielded Metal Arc Welding (SMAW) parame- ters on mechanical properties of low-carbon, mild and stainless-steel welded joints: A review
}

\author{
S. Farrukh Haider ${ }^{1}$, M. M. Quazi ${ }^{2}$, Jahanzeb Bhatti ${ }^{3}$, M Nasir Bashir $^{4 *}$, Imran Ali ${ }^{5}$ \\ ${ }^{1,4}$ National University of Sciences and Technology (NUST), Islamabad, Pakistan \\ ${ }^{2}$ Faculty of Mechanical \& Automotive Engineering Technology, Universiti Malaysia Pahang, \\ 26600 Pekan, Pahang, Malaysia \\ ${ }^{3}$ Department of Metallurgical Engineering, NED University of Engineering and Technology, Karachi, Pakistan \\ ${ }^{5}$ Institute of Metal Research, Chinese Academy of Science, Shenyang 110016, China
}

\section{Keywords \\ Welding current \\ Welding speed \\ Hardness \\ Tensile strength \\ Steel specimens}

Received: 6 May 2019

Accepted: 8 July 2019

Published: 31 October 2019

\begin{abstract}
Conventionally, the metal joining process used to be carried out using fasteners and rivets. Since the advancements in technology, the metal joining process is now performed via welding. Because welding affects the mechanical properties, the importance of welding parameters to determine the mechanical properties of welded plates is considered. This research reviews the impact of Shielded Metal Arc Welding (SMAW) parameters on the mechanical properties of low-carbon, mild, and stainless-steel welded joints. It is necessary to understand the welding parameters to get the product of desired quality. In the past, the studies, the welding parameters: welding speed and current, were considered to find the impact via destructive testing (DT), including hardness and tensile tests. The present study aims to review the impact of welding parameters on hardness and tensile tests carried out in the past.
\end{abstract}

(C) 2019 The Author(s). Published by TAF Publishing.

\section{INTRODUCTION}

Welding is a process used to join the two work piece surfaces together to form a single product. In today's world, the welding is used to join and make various materials and products. Many industries such as construction, automotive, shipbuilding and aerospace, employ welding as their major metal joining process. The welding process may utilize heat, energy and pressure or combination of all [1]. The welding is performed on the intersection of two surfaces with or without the filler material. There is great future of welding, as new methods are being developed to weld dissimilar metals with complicated shapes and sizes [2,3].

The Shielded Metal Arc Welding SMAW is a welding process, also called "stick welding", which is widely used in the construction industries and in repairing, as it offers more

\footnotetext{
${ }^{*}$ Corresponding author: M Nasir Bashir

†email: nasir@pnec.nust.edu.pk
}

flexibility and portability. It utilizes a consumable electrode which is coated with protective coating called flux which provides the shielding of joint. During welding, the flux coating on the electrode starts to burn that causes the release of shielding gas which protects the base metal and weldment from the atmospheric contamination. The main atmospheric contaminants are Hydrogen and Oxygen, which causes defects in welding such as cracks and porosity, respectively. Figure 1. Shows the layout of SMAW welding on steel plate. There are different welding parameters in SMAW that have an impact on welding productivity and quality. Also, the use of SMAW welding incurs low cost as compared to other welding techniques. It is broadly used welding process as it offers the simplicity of use and lowcost maintenance $[4,5]$. 

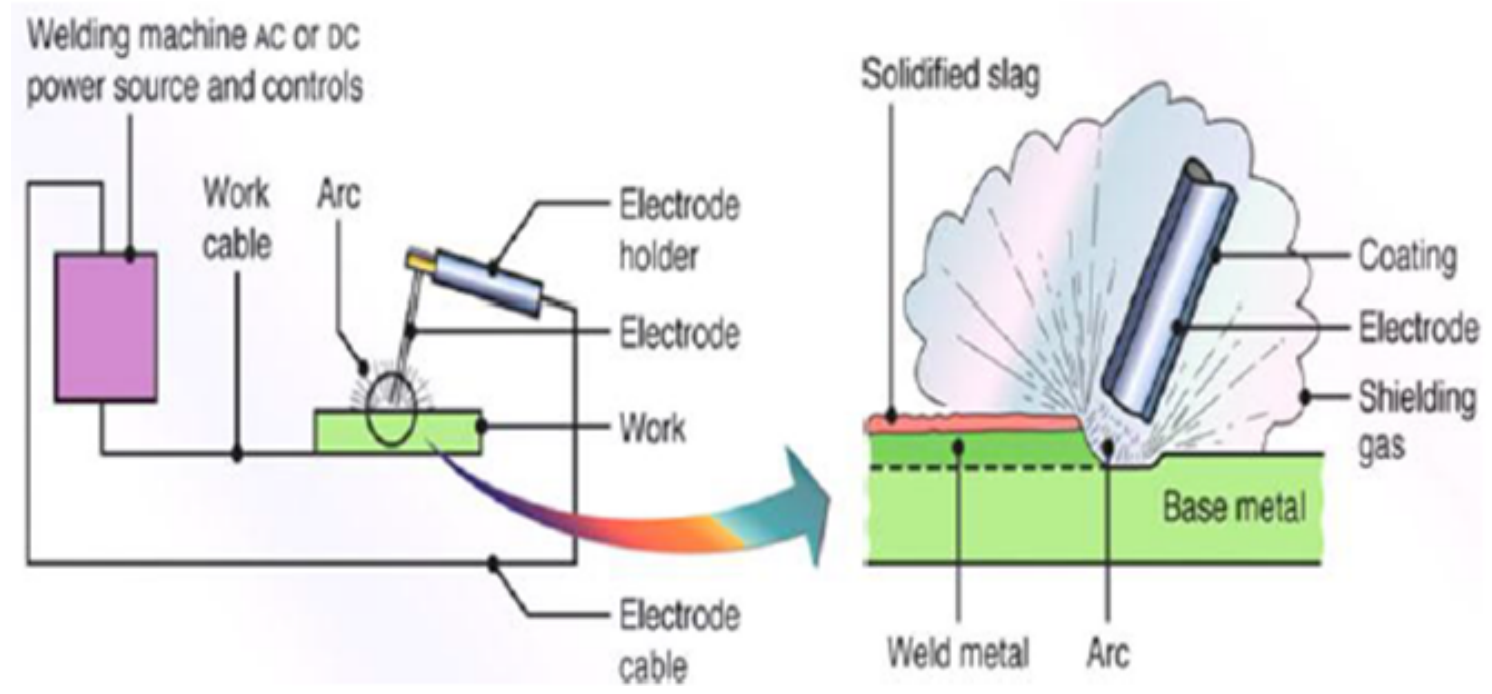

Fig. 1. SMAW process on steel plate [2]

\section{A. Mild Steel (MS)}

It is the economical form of steel offering suitable mechanical properties for various applications. It is hard, weld-able and durable, but it rusts easily. It contains $0.29 \%$ carbon and can be magnetized easily. It is widely used in structural work and in automotive industries.

\section{B. Low-Carbon Steel}

This type of steel has a $0.16-0.29 \%$ carbon content and is widely used. It has low tensile strength but high ductility which makes it excellent for welding and machining. It cannot be hardened by performing heat treatment, instead cold working is used. Applications of low carbon steel includes; automotive body parts, structural beams, channels, angle, pipes and in construction work [6].

\section{Stainless-Steel (SS)}

It is an iron-alloy which comprises of at least $11 \%$ chromium which prevents the material from rusting and makes it more heat-resistant. It is a hard and ductile. The chromium forms a layer of oxide on the steel surface called the "passive layer". This layer makes the surface resistant to corrosion. Thus, greater chromium content will increase the anti-corrosion properties of stainless steel. It is used mostly in automotive, construction and power generation industries [7].

\section{Welding Speed}

Welding speed is the rate of distance covered by an electrode along the seam. Increasing the speed and maintaining arc voltage, the width of welding bead will be reduced. There is an optimum point at which penetration of weld will reach maximum and going beyond this optimum point will decrease the penetration [8].

\section{E. Welding Current}

Welding current is a significant parameter in welding which has great impact on the fusion depth, depth of penetration and feed rate. The heat generated during welding depends on the current used for the size of electrode. So correct current is necessary for high quality weld [8].

The impact of parameters; welding speed and current on mechanical properties of joints was studied in this research. Many experiments were performed carry out the analysis on steel-welded specimens.

\section{RESEARCH METHODS}

The research methods define the experimental procedure for conducting the experiment. The input and the output parameters for the research papers are tabulated as follows.

\section{A. Input Parameters}

Following are the input variables that were set for the preparation of samples.

The Table 1 shows the materials and methodology used in the research papers. The dimensions column represent the size of plates/pipes welded using SMAW technique. The joint type represents the edge preparation and the position of joining the plates/pipes together. The input parameters are the welding current and speed to obtain the optimum output/testing parameters. 
TABLE 1

THE INPUT PARAMETERS FOR THE SMAW TECHNIQUE

\begin{tabular}{|c|c|c|c|c|c|c|c|}
\hline S No. & $\begin{array}{l}\text { Materials used for } \\
\text { SMAW Technique }\end{array}$ & Joint Type & Dimensions & No. of Samples & Current (A) & Speed & Reference No. \\
\hline 1 & Mild Steel & $\begin{array}{l}\text { Single V, Double V, } \\
\text { Square Butt }\end{array}$ & $\begin{array}{l}150 \mathrm{~mm} \times 50 \mathrm{~mm} \times \\
6 \mathrm{~mm}\end{array}$ & $\begin{array}{l}12 \text { samples (4 sam- } \\
\text { ples for each Joint } \\
\text { type) }\end{array}$ & $\begin{array}{l}90,100,110,120 \\
\text { (Same current for } \\
\text { first } 4 \text { samples and } \\
\text { so on) }\end{array}$ & $\begin{array}{ll}142.85, & 157.84, \\
157.89, & 199.99, \\
171.42, & 176.47, \\
193.54, & 222.22, \\
152.28, & 162.42, \\
190.35, & 205.47 \\
\mathrm{~mm} / \mathrm{min} & \\
\end{array}$ & [8] \\
\hline 2 & $\begin{array}{l}\text { Medium Carbon } \\
\text { Steel Rods }\end{array}$ & - & $12 \mathrm{~mm}$ diameter & $\begin{array}{l}20 \text { samples (4 un- } \\
\text { welded and } 16 \\
\text { beveled with } 30^{\circ} \\
\text { angle) }\end{array}$ & & - & [9] \\
\hline 3 & A36 Mild Steel & - & $\begin{array}{l}\text { For Hardness test: } \\
(5.5 \mathrm{~cm} \times 1 \mathrm{~cm} \times \\
1 \mathrm{~cm})\end{array}$ & 6 samples & $\begin{array}{l}70,80,90, \quad 100 \\
110,120\end{array}$ & - & {$[10]$} \\
\hline 4 & $\begin{array}{l}\text { Low carbon round } \\
\text { bars }\end{array}$ & - & $12 \mathrm{~mm}$ diameter & Length $=50 \mathrm{~mm}$ & 7 samples & $\begin{array}{l}100,120,140 \\
\text { (same current } \\
\text { value for } 7 \text { sam- } \\
\text { ples) }\end{array}$ & - [11] \\
\hline 5 & AISI 1020 & Square butt & - & 3 samples & $90,105,120$ & & {$[12]$} \\
\hline 6 & $\begin{array}{l}\text { AISI } 1018 \text { Low Car- } \\
\text { bon steel }\end{array}$ & $\begin{array}{l}\text { Single V ( bevel of } \\
60^{\circ} \text { ) }\end{array}$ & $\begin{array}{l}400 \mathrm{~mm} \times 200 \mathrm{~mm} \times \\
6 \mathrm{~mm}\end{array}$ & 4 samples & $55,75,80,90$ & & [13] \\
\hline 7 & AISI 1020 Steel & Square groove butt & $\begin{array}{l}100 \mathrm{~mm} \times 50 \mathrm{~mm} \times \\
10 \mathrm{~mm}\end{array}$ & 18 samples & $95,110,125$ & - & [14] \\
\hline 8 & $\begin{array}{l}\text { St. } 37 / 2 \text {, St. } 44 / 2 \text {, } \\
\text { St. } 52 / 3\end{array}$ & Single V butt & $\begin{array}{l}\text { Plates }(160 \mathrm{~mm} \quad \mathrm{x} \\
90 \mathrm{mmx} 5 \mathrm{~mm}) \\
\text { Groove angles }(40, \\
\left.60,80,100^{\circ}\right)\end{array}$ & 16 samples & $90,100,110,120$ & - & [15] \\
\hline 9 & $\begin{array}{l}\text { AISI } 304 \text { Stainless } \\
\text { Steel }\end{array}$ & Single V butt & $\begin{array}{l}\text { Plates having } 3 \mathrm{~mm} \\
\text { thickness and } \\
\text { groove angle of } 60^{\circ}\end{array}$ & 3 samples & $70,80,90$ & - & {$[16]$} \\
\hline 10 & $\begin{array}{ll}\text { Stainless } & \text { Steel } \\
\text { Type 304L } & \end{array}$ & Double V groove & $\begin{array}{l}\text { Plates with } 12 \mathrm{~mm} \\
\text { thickness, root } \\
\text { gap of } 2 \mathrm{~mm} \text {, and } \\
\text { groove angle of } 70^{\circ}\end{array}$ & 1 sample & 120 & $60 \mathrm{~mm} / \mathrm{min}$ & {$[17]$} \\
\hline 11 & $\begin{array}{l}\text { HSLA-80 steel } \\
\text { plates }\end{array}$ & Double V groove & $\begin{array}{l}\text { Plates }(500 \mathrm{~mm} \times \\
250 \mathrm{~mm} \times 30 \mathrm{~mm}) \\
\text { and groove angle of } \\
60^{\circ}\end{array}$ & 3 samples & $100,140,150$ & - & [18] \\
\hline 12 & $\begin{array}{l}\text { IS } 2062 \text { Structural } \\
\text { Steel }\end{array}$ & $\begin{array}{l}\text { Straight edge, sin- } \\
\text { gle bevel at } 30^{\circ} \text {, } \\
\text { and single } V \text { at } 60^{\circ}\end{array}$ & $\begin{array}{l}\text { Plates }(100 \mathrm{~mm} \times \\
100 \mathrm{~mm} \times 6 \mathrm{~mm}) \\
\text { with root gap of } \\
3 \mathrm{~mm}, 2 \mathrm{~mm} \text {, and } \\
2 \mathrm{~mm} \text {, respectively. }\end{array}$ & 3 samples & $80,90,100,110$ & $\begin{array}{l}123,136,141,149 \\
\mathrm{~mm} / \mathrm{min}\end{array}$ & [19] \\
\hline 13 & $\begin{array}{l}\text { S45C Steel at } 150 \text {, } \\
250 \text {, and } 300^{\circ} \mathrm{C}\end{array}$ & - & - & 3 samples & - & - & [20] \\
\hline 14 & Low carbon steel & - & $\begin{array}{l}150 \mathrm{~mm} \times 50 \mathrm{~mm} \times \\
8 \mathrm{~mm}\end{array}$ & 8 samples & $\begin{array}{l}140 \text { A for } 4 \text { sam- } \\
\text { ples and } 170 \text { A for } \\
\text { the other } 4 \text { sam- } \\
\text { ples }\end{array}$ & - & {$[21]$} \\
\hline 15 & $\begin{array}{l}\text { AISI } 1020 \text { Low car- } \\
\text { bon Steel }\end{array}$ & - & - & 6 samples & 80,90 & - & [22] \\
\hline 16 & $\begin{array}{l}\text { (A } 106 \text { Gr. B } \\
\text { Sch.40) Carbon } \\
\text { steel pipe }\end{array}$ & $\begin{array}{l}\text { 6G (welding posi- } \\
\text { tion) }\end{array}$ & $\begin{array}{l}4 \text { in diameter } \\
\text { Length of } 300 \mathrm{~mm}\end{array}$ & 2 samples & - & - & {$[23]$} \\
\hline 17 & Mild Steel & Butt Joint (1G) & $\begin{array}{l}\text { Plates } \\
\text { (width=24mm, } \\
\text { Thickness }=5 \mathrm{~mm} \text { ) }\end{array}$ & 4 samples & $76,87,105,123$ & - & {$[24]$} \\
\hline 18 & Mild Steel & - & - & 3 samples & $250,300,350$ & $1.2,1.8,2.5 \mathrm{~cm} / \mathrm{s}$ & {$[25]$} \\
\hline 19 & Low carbon steel & Butt Joint & $\begin{array}{l}\text { Plates }(60 \mathrm{~mm} \times \\
40 \mathrm{~mm} \times 10 \mathrm{~mm}) \\
\text { and root gap of } \\
3 \mathrm{~mm}\end{array}$ & 4 samples & $100,120,150,200$ & $40,44,48,66$ & [26] \\
\hline
\end{tabular}

\section{B. Testing Parameters}

The testing parameters show the DT such as tensile strength, hardness test values which are tabulated. The Ta- ble 2 includes the testing parameters or mechanical properties which are tensile strength, elongation and hardness. The changes in the current and welding speed has impacted the test results of the mechanical properties. 
TABLE 2

THE TESTING PARAMETERS FOR SMAW TECHNIQUE

\begin{tabular}{|c|c|c|c|c|}
\hline S.No & Tensile Strength & \% Elongation & Hardness & Reference No. \\
\hline 1 & $\begin{array}{lccc}386.221, & 418.64, & 435.59, & 427.11, \\
377.40, & 387.74, & 386.27, & 375.66 \\
375.64, & 394.16,386.25,377.49 \mathrm{MPa}\end{array}$ & $\begin{array}{lllll}25.41, & 18.59, & 20.39, & 19.90, & 22.40 \\
23.35, & 25.42, & 22.80, & 22.21, & 24.11 \\
25.22, & 23.14 & & & \end{array}$ & - & [8] \\
\hline 2 & - & $0,0.9,1,1.2,1.5,1.8,2.1,3.0,6.4$ & - & [9] \\
\hline 3 & - & - & $114,101.1,95,85.3,73.6,60 \mathrm{HBN}$ & [10] \\
\hline 4 & $450,448,446,430,415,410,405 \mathrm{MPa}$ & - & $350,300,280,260,200,200,200 \mathrm{HBN}$ & [11] \\
\hline 5 & $191,210,250 \mathrm{MPa}$ & - & - & [12] \\
\hline 6 & $452.33 \mathrm{MPa}$ (at 55A) & - & $140 \mathrm{HV}$ & [13] \\
\hline 7 & $\begin{array}{l}413,414,416,421,428,434,425,435 \\
445,495,514,515,514,513,529, \\
540,578,588 \mathrm{MPa}\end{array}$ & - & - & [14] \\
\hline 8 & $\begin{array}{l}292.5,250,380,290,250,282.5,330 \\
342.5,327.5,262.5,452.5,337.5,340, \\
375,442.5,282.5 \mathrm{MPa}\end{array}$ & $\begin{array}{l}9,10.6,5,10.2,6.2,8.4,7,15,11.6,4.6 \\
10.2,19,12.2,12.2,8.4,11\end{array}$ & $\begin{array}{l}42.5,39.4,52.4,43.7,41.48,43.61 \\
51.11,43.28,43,38.9,49.7,41,42.7 \\
42.4,50.3,38.1\end{array}$ & {$[15]$} \\
\hline 9 & $510.22,555.56,623.33 \mathrm{MPa}$ & - & - & {$[16]$} \\
\hline 10 & - & - & - & [17] \\
\hline 11 & - & - & $300,305,290$ & [18] \\
\hline 12 & $462.25,515.20,549.30,601.70$ & $17.50,18.5,15.69,17.65$ & $180.8,196.30,222.30,212.4$ & [19] \\
\hline 13 & $33.2,40.1,42.0 \mathrm{kgf} / \mathrm{mm} 2$ & - & $37.25,38.8,40.49$ & {$[20]$} \\
\hline 14 & - & - & $\begin{array}{l}751,813,303,311,503,783,299,311 \\
\text { HV }\end{array}$ & {$[21]$} \\
\hline 15 & $\begin{array}{l}404.549,375.4,487.6,462.8,436.8 \\
411.9\end{array}$ & - & $\begin{array}{l}30.6,28.28,36.46,33.10,37.6,35.340 \\
\text { HRC }\end{array}$ & {$[22]$} \\
\hline 16 & $312.57,311.96 \mathrm{MPa}$ & - & 185,184 & {$[23]$} \\
\hline 17 & $52,189,268,355 \mathrm{MPa}$ & - & $93,99,99,102$ HRC & {$[24]$} \\
\hline 18 & - & - & $284.85 \mathrm{BHN}$ & {$[25]$} \\
\hline 19 & $480,490,485,525$ & - & $43,44.5,44,43.5 \mathrm{HB}$ & {$[26]$} \\
\hline
\end{tabular}

\section{EFFECT OF WELDING PARAMETERS ON MECHANICAL PROPERTIES OF STEEL JOINTS}

The welding parameters have the significant impact on the strength and quality of the weldment. The parameters such as welding current, speed and arc voltage affects the mechanical properties such as hardness and tensile strength of the welded joint. Generally, the increase in the welding current increases the hardness and reduces the tensile strength. Moreover, the increase in the welding speed increases the hardness and tensile strength of the joint.

\section{A. Effect of Welding Current}

[8] investigated the impact of current on the tensile properties of mild-steel joints. In this work, the ultimate tensile strength was found using tensile testing machine. The results showed that out of four selected current values, the optimum value of current which gave the highest tensile property value of $120 \mathrm{~A}$. [27] conducted a research on the analysis and optimization of SMAW parameters on hardness and tensile values of mild steel plate. It was observed the higher current values caused the hardness and tensile strength to increase.

[9] carried out the research on the hardness and tensile values of medium-carbon steel joints via SMAW process focusing on the filler metal, parent metal and Heat-Affected Zone (HAZ). The results showed that the tensile strength value of the medium-carbon steel joint in HAZ had lower impact strength and higher values of hardness and tensile strength relative to the parent and the weld metal. But due to increased hardness, the metal was found to be more brittle. [28] described his research on GMAW and SMAW process which showed that current, voltage, arc length, speed and electrode angle affected the penetration and bead width on MS2062 mild steel plate. The highest strength welded joint was produced by SMAW process. Increasing the current resulted in the increase in bead width and penetration. Increasing the speed, decreased the penetration and bead width. The optimum penetration and bead width occurred at current of $100 \mathrm{~A}$, angle of 70 degrees, arc length of $3 \mathrm{~mm}$ and voltage of $24 \mathrm{~V}$.

[10] analyzed the impact of welding current on mechanical properties of A-36 steel joints using SMAW process. The current range of $70 \mathrm{~A}$ to $120 \mathrm{~A}$ was selected. The hardness was tested and the highest hardness (114 HB) was found at lowest current value (70A) because the solidification time was less as compared to the current setting at $120 \mathrm{~A}$.

[11] performed the investigation on the relation between the control variables and Post-Weld Heat Treatment (PWHT) of low-carbon steel joints. The sample consisted of Three Hundred and Sixty pieces. The welding current was varied from $100 \mathrm{~A}, 120 \mathrm{~A}$ and $140 \mathrm{~A}$. It was found that the higher current values resulted in an increased tensile and hardness values. Highest values of hardness and tensile strength were observed at 140 A to be $457 \mathrm{HB}$ and 742.5 
$\mathrm{MPa}$, respectively.

[12] conducted an experimental study to determine the influence of welding variables on low carbon welded steel plates strength (AISI 1020). The parameters: polarity, angle of electrode and current were varied. The values of current were set at $90 \mathrm{~A}, 105 \mathrm{~A}$ and $120 \mathrm{~A}$. The polarity was set at 1 (DCEP) and 2 (DCEN). The electrode angles were varied from 60, 75 and 90 degrees. The results depict that the higher current values increased the tensile strength. Hence, the maximum tensile strength was $259 \mathrm{MPa}$ and at the current value of $120 \mathrm{~A}$.

[13] investigated the impact of SMAW variables on hardness and tensile values of low-carbon steel welded joints. The current was varied from $55 \mathrm{~A}$ to $90 \mathrm{~A}$. The greater current values resulted in higher tensile and hardness values. The optimum values of tensile strength and hardness obtained were $452.33 \mathrm{MPa}$ and $195 \mathrm{HV}$.

[14] determined the impact of current, polarity and angle of electrode on tensile property value of low-carbon steel plates. The current was varied from 95A, 110A, and 125A. The electrode angles were varied from 65,75 , and 85 '. The polarity used were DCEP and DCEN. The maximum value of tensile strength obtained was $588 \mathrm{MPa}$ at Polarity of DCEN, welding current of $125 \mathrm{~A}$ and electrode angle of 85 '.

[15] evaluated the impact of welding variables on the mechanical properties of steel grades (St.52/3, St.37/2 and St.44/2) using SMAW process. The samples were machined at $40^{\prime}, 60^{\prime}, 80^{\prime}, 100^{\prime}$. Taguchi approach was employed to determine the most dominant parameter. The results showed that the carbon percentage (C.E) was the most dominant parameter relative to the heat input and groove angle which resulted in the tensile strength of $442.5 \mathrm{MPa}$.

[16] performed the research on impact of current on tensile values of stainless-steel (AISI 304) specimens. Moreover, the current was varied from $70 \mathrm{~A}$ to $90 \mathrm{~A}$ with a $10 \mathrm{~A}$ successive increment. The highest and lowest tensile strength values were found at the current of $90 \mathrm{~A}$ and $70 \mathrm{~A}$, respectively. The highest and lowest tensile strengths obtained were 632 and 498.66 MPa.

[17] conducted a research on the impact of TIG and SMAW process on (304L) Stainless-Steel welded plates distortion using different joint types. The lower angular distortion was obtained using TIG process while the maximum angular distortion was found with SMAW process. The positive effect of distortion was found at greater length and electrode diameter. The negative effect of distortion occured at higher current values.

[29] conducted the study on optimization of welding variables such as welding speed, current and voltage on a mild steel specimen. The relationship was determined between welding deposition area and welding variables using factorial design approach. The results showed that weld deposit area increases by increasing the welding current and voltage but decreases if welding speed is reduced. The most impactful welding variable found was the welding voltage. The factorial design tool effectively showed the relation of welding variable and weld deposition area.

[18] provided a comparison of different heat treatment conditions in relation with HSLA-80 steel using pre- or post-weld heat treatment on mechanical properties and microstructure of specimen. The results showed little impact of heat treatment on mechanical and microstructural properties. Specimen without undergoing pre-heating had higher hardness. The toughness was higher for without pre or post-heat treatment.

[19] studied the impact on mechanical and angular distortion of SMAW parameters on welding butt joints in flat position of hot-rolled structural steel. The main variables taken into account were welding current, voltage and speed. The three samples were prepared having straight edge, single beveled at $30^{\circ}$ and single $\mathrm{V}$ groove of $60^{\circ}$. The tensile strength increased with the increase in welding current. The V-grooved joint showed the maximum tensile strength of 601.7 MPA and yield strength $447.6 \mathrm{MPa}$ at the current of $110 \mathrm{~A}$. The impact energy values increased for single $\mathrm{V}$ groove at $60^{\circ}$ and single bevel at $30^{\circ}$ when the welding current and speed were increased. The increase in welding current decreased the distortion for single bevel at $30^{\circ}$ and single groove at $60^{\circ}$ but distortion increased for straight-edge. [20] analyzed the impact of heat treatment on S45 C Steel after SMAW welding. The three specimens were prepared with temperatures of $150^{\circ} \mathrm{C}, 250^{\circ} \mathrm{C}$, and $300^{\circ} \mathrm{C}$. The Annova variance analysis technique was used for hardness and tensile test date.The results depict that the heating changed the mechanical properties of specimens. The higher heating temperature increased the tensile strength and the maximum strength obtained was $42 \mathrm{kgf} / \mathrm{mm}^{2}$ at $300^{\circ} \mathrm{C}$. The hardness increased to 40.83 at $300^{\circ} \mathrm{C}$. The toughness decreased as the temperature was increased and at $300^{\circ} \mathrm{C}$, the value obtained was $66.87 \mathrm{~J}$. Higher temperatures are recommended for higher hardness and strength.

[21] studied on optimizing welding variables to employ hard facing process via SMAW technique to form a wear resistant layer over mild steel specimen. The variables to be considered were electrode type, current and number of layers. The eight samples of mild steel were prepared. The results showed that the micro hardness was increased when number of layers and electrode types were increased 
but decreased with increase in welding current. For future work, the toughness, bending and corrosion testing can be performed depending on the service condition of hard faced part.

[22] investigated the effect of different welding fillers and current values on mechanical properties of low carbon steel specimen. The two way annova analysis technique was used. The welding filler used were E6013, E7016, and E7018 and current values were $80 \mathrm{~A}$ and $90 \mathrm{~A}$. The mechanical properties were tensile strength and hardness. There was a significant impact of welding current and welding fillers on mechanical properties. The experiment showed that the increase in current resulted in a decrease in tensile strength and hardness. The maximum strength was obtained with E7016 welding filler and maximum hardness was produced with E7018 welding filler at $80 \mathrm{~A}$.

[23] performed an experimental investigation to analyse the combination of electrodes on LPG pipes to get high quality weld using SMAW technique. The two carbon steel pipes having thickness of 4 in. were selected for welding in 6-G position. The results showed that higher hardness is obtained at low current and at the electrode combination of E7018 and E6010. This combination gives high hardness and toughness values.

[24] conducted a research on optimization of SMAW parameters for welding mild steel workpieces. The study showed that different input paramters affect the weld quality via mechanical testing. The thirty six welded mild steel samples were selected based on taguchi orthogonal array on trial experiment. The hardness, tensile and toughness tests were performed. The results depict that high quality weld having maximum tensile strength was obtained at the current, groove and voltage of $123 \mathrm{~A}, 60^{\circ}$ and $27 \mathrm{~V}$. The tensile strength increased with higher groove angle. The toughness decreased with lower groove angle.
[25] performed the experimentation on the strength and microstructural characteristics of hard faced mild steel specimen using SMAW process. The hard facing will be done using chromium alloy steel in the form of electrodes. The welding speed, voltage and current were varied. The experiment was performed using Taguchi's L9 orthogonal array and results of hardness and impact strength were obtained. The results showed that the hardness and impact strength of hard faced part was increased.

[26] investigated the impact of varying welding variables; current, speed and arc voltage on mechanical properties of low-carbon steel joint. The results showed that the increase in the welding speed to the value of $66.67 \mathrm{~mm} / \mathrm{min}$ caused the tensile strength of $440 \mathrm{MPa}$ and hardness to $49 \mathrm{HB}$. The current and voltage increased the hardness value but decreased the yield and tensile strength.

\section{CONCLUSION AND RECOMMENDATIONS}

The impact of changing the welding current and speed on mechanical properties such as hardness and tensile strength values were reviewed to show the behavior of low carbon, mild carbon and stainless-steel joints. The results show that varying the welding parameters greatly affected mechanical properties of different steel joints. Mainly, the current caused the higher hardness values which would require further heat treatment to prevent brittle failure. Also, higher current values resulted in lower tensile strength values due to formation of defects.

The research limitations can be the higher current values will decrease the tensile strength and hardness. This is because the cooling rate decreases which will cause coarse grains to form. Moreover, the welding defects will also increase at higher current values. For future work, it is recommended to consider more input/output parameters along with metallographic examination.

\section{REFERENCES}

[1] D. Pathak, R. P. Singh, S. Gaur, and V. Balu, "Influence of groove angle on hardness and reinforcement height of shielded metal arc welded joints for low carbon AISI 1016 steel plates," Materials Today Proceedings, vol. 5, no. 8, pp. 56-80, 2020. doi: https://doi.org/10.1016/j.matpr.2020.05.597

[2] Wikipedia, "Welding." [Online]. Available: https://bit.ly/3ob0mEm

[3] Y. X. Lee and Z. W. Zhong, "A study of the relationship between adverse weather conditions and flight delay," Journal of Advances in Technology and Engineering Research, vol. 2, no. 4, pp. 113-117, 2016. doi: https://doi.org/10.20474/ jater-2.4.2

[4] G. Karthik, "Comparative evaluation of mechanical properties and micro structural characteristics of 304 stainless steel weldments in TIG and SMAW welding processes," International Journal of Current Enginerring and Technology, vol. 2, no. 2, pp. 200-206, 2013. doi: http://dx.doi.org/10.14741/ijcet/spl.2.2014.36

[5] N. Semsri., C. Torasa., K. Samerjai., M. Suksombat, and P. Sinpeng, "Electricity-generating wind turbine from electric bicycle motor," International Journal of Technology and Engineering Studies, vol. 2, no. 4, pp. 101-109, 2016. doi: https: 
//doi.org/10.20469/ijtes.2.40002-4

[6] M. A. Gaodi and D. Sangotra, "A review paper on effect of varying welding heat inputs on microstructure, mechanical properties and corrosion behaviours of ferritic stainless steel \& mild steel," International Journal of Modelling Engineering Resolution, vol. 4, no. 1, pp. 105-109, 2014.

[7] Thermo Fisher, "What is stainless steel?" 2014. [Online]. Available: https://bit.ly/35ib8QC

[8] R. Jha and A. Jha, "Influence of welding current and joint design on the tensile properties of SMAW welded mild steel joints," International Journal of Engineering Research and Applications, vol. 4, no. 6, pp. 106-111, 2014.

[9] R. Mohammed, M. Abdulwahab, and E. Dauda, "Properties evaluation of shielded metal arc welded medium carbon steel material," International Journal of Innovative Research in Science, Engineering and Technology, vol. 2, no. 8, pp. 345-367, 2013.

[10] I. Asibeluo and E. Emifoniye, "Effect of arc welding current on the mechanical properties of A36 carbon steel weld joints," International Journal of Mechanical Engineering, vol. 2, no. 9, pp. 32-40, 2015.

[11] J. Olawale, S. Ibitoye, K. Oluwasegun, M. Shittu, R. Ofoezie et al., "Correlation between process variables in Shielded Metal-Arc Welding (SMAW) process and Post Weld Heat Treatment (PWHT) on some mechanical properties of low carbon steel welds," Journal of Minerals and Materials Characterization and Engineering, vol. 11, no. 9, pp. 891-895, 2012. doi: https://doi.org/10.4236/jmmce.2012.119085

[12] A. Shukla and V. Joshi, "Experimental study of shielded metal arc welding parameter on weld strength for aisi 1020 using response surface methodology," Journal of Engineering, vol. 9, no. 5, pp. 1123-1126, 2017.

[13] R. Chiong, N. Khandoker, S. Islam, and E. Tchan, "Effect of SMAW parameters on microstructure and mechanical properties of AISI 1018 low carbon steel joints: An experimental approach," in IOP Conference Series: Materials Science and Engineering, London, UK, 2019.

[14] D. Pathak, R. P. Singh, S. Gaur, and V. Balu, "Experimental investigation of effects of welding current and electrode angle on tensile strength of shielded metal arc welded low carbon steel plates," Materials Today Proceedings, vol. 1, no. 3, pp. 245-267, 2020. doi: https://doi.org/10.1016/j.matpr.2020.01.146

[15] S. Zoalfakar and A. Hassan, "Analysis and optimization of shielded metal arc welding parameters on mechanical properties of carbon steel joints by taguchi method," International Journal of Advanced Engineering and Global Technology, vol. 1, no. 5, pp. 56-90, 2017.

[16] E. Widodo, I. Iswanto, M. A. Nugraha, and K. Karyanik, "Electric current effect on mechanical properties of SMAW-3G on the stainless steel AISI 304," in MATEC Web of Conferences, New York, NY, 2018.

[17] D. Kumar and M. Dharamvir, "Study and analysis of the effect of welding process on distortion with 304L stainless steel weld joints," International Journal of Engineering, vol. 6, no. 2, p. 212-216, 2017.

[18] L. De Jesus Jorge, V. S. Cândido, A. C. R. da Silva, F. da Costa Garcia Filho, A. C. Pereira, F. S. da Luz, and S. N. Monteiro, "Mechanical properties and microstructure of SMAW welded and thermically treated HSLA-80 steel," Journal of Materials Research and Technology, vol. 7, no. 4, pp. 598-605, 2018. doi: https://doi.org/10.1016/j.jmrt.2018.08.007

[19] A. K. Yadav, A. Kumar, C. P. N. Singh, A. K. Singh, and M. S. Nand, "Studies on impact of welding parameters on angular distortion and mechanical properties of structural steel welded by SMAW," Journal of Engineering, vol. 1, no. 5, pp. 56-70, 2019.

[20] H. Abbas, A. Y. Aminy et al., "The effects of Shielded Metal Arc Welding (SMAW) welding on the mechanical characteristics with heating treatment inn S45c steel," Journal of Physics, vol. 962, no. 1, pp. 56-80, 2018. doi: https: //doi.org/10.1088/1742-6596/962/1/012063.

[21] A. Rude and M. D. Pimpalgaonkar, "Optimization of process parameter in hardfacing by Shield Metal Arc Welding (SMAW)," International Research Journal of Engineering and Techonology, vol. 5, no. 8, pp. 232-236, 2018.

[22] A. M. Tahir, N. A. M. Lair, and F. J. Wei, "Investigation on mechanical properties of welded material under different types of welding filler (shielded metal arc welding)," in AIP Conference Proceedings, California, CA, 2018.

[23] R. Selvam and S. Jacob, "Experimental investigation and analysis of smaw processed carbon steel pipes," International Journal of Mechanical and Production Engineering Research and Development, vol. 8, no. 5, pp. 29-40, 2018. doi: https: //doi.org/10.24247/ijmperdoct20185.

[24] L. S. K. Weerasekralage, M. Karunarathne, and S. Pathirana, "Optimization of Shielded Metal Arc Welding (SMAW) process for mild steel," Journal of Engineering, vol. 1, no. 6, pp. 345-367, 2019. doi: https://doi.org/10.13140/RG.2.2. 
23458.58560.

[25] D. Benne and D. D. Choudhary, "Experimentation and analysis of strength and microstructural parameters of mild steel specimen hardfaced by chromium zedalloy-350 using shielded metal arc welding (smaw) process." Research and Engineering Journal, vol. 2, no. 1, pp. 1-5, 2018.

[26] S. Talabi, O. Owolabi, J. Adebisi, and T. Yahaya, "Effect of welding variables on mechanical properties of low carbon steel welded joint," Advances in Production Engineering \& Management, vol. 9, no. 4, pp. 181-186, 2014. doi: https: //doi.org/10.14743/apem2014.4.186

[27] A. Dadi, P. B. Goyal, and M. H. Patel, "A review paper on "optimization of shielded metal arc welding parameters for welding of (Ms) Sa-516 Gr. 70plate by using taguchi approach," International Journal of Scientific Research in Science and Technology, vol. 4, no. 5, pp. 1536-43, 2018.

[28] B. Sharma and S. Goyal, "Parametric optimization of shielded metal arc welding of Mild Steel (MS) 2062 using taguchi method," Journal of Advanced Research in Mechanical Engineering and Technology, vol. 3, no. 3, pp. 112-134, 2016.

[29] A. K. Kalyani, K. Brajesh, A. Senyshyn, and R. Ranjan, “Orthorhombic-tetragonal phase coexistence and enhanced piezoresponse at room temperature in $\mathrm{Zr}$, Sn, and $\mathrm{Hf}$ modified $\mathrm{BaTiO}_{3}$, " Applied Physics Letters, vol. 104, no. 25, pp. 252-906, 2014. doi: https://doi.org/10.1063/1.4885516 